\title{
Impact of locoweed poisoning on grazing steer weight gains
}

\author{
MICHAEL H. RALPHS, DAVID GRAHAM, GLEN DUFF, BRYAN L. STEGELMEIER, AND LYNN F. JAMES
}

Authors are rangeland scientist, USDA/ARS Poisonous Plant Lab, 1150 E. 1400 N., Logan Ut 84341; extension county agent, Clayton N.M.; director NMSU Clayton Research Station; veterinary pathologist; and director USDA/ARS Poisonous Plant Lab.

\begin{abstract}
Emaciation is one of the clinical signs of locoweed poisoning but few studies have documented impacts of locoweed poisoning on weight gains. Stocker steers (British $\mathbf{x}$ Continental cross, 200-210 kg) were grazed on locoweed-infested, short-grass prairie in 1996 and 1997 in northeast New Mexico. Each year, half the steers were averted to locoweed to allow them to graze locoweed-infested pastures without eating locoweed. They did not graze locoweed and steadily gained weight $(0.50 \mathrm{~kg} / \mathrm{day}$ in 1996 and $0.71 \mathrm{~kg} / \mathrm{day}$ in 1997). The other group of steers were allowed to graze locoweed under natural grazing conditions and became intoxicated. Weight gains were not affected for the first 3 weeks, but thereafter the steers lost weight in both years. In 1996, nonaverted steers consumed locoweed for a season average of $20 \%$ of bites. They were severely intoxicated and did not begin gaining weight for $\mathbf{5 0}$ days after they stopped eating locoweed. Steers in the 1997 trial consumed less locoweed (11\% of bites) than those in 1996 and they recovered more rapidly. Seasonal weight gains were 21 to $30 \mathrm{~kg}$ less for locoed steers than control steers in 1996 and 1997, respectively. Locoweed poisoning will cause weight loss, and severely intoxicated cattle require a lengthy recover period after they cease grazing locoweed before weight gains resume. Stocker cattle should not be placed on locoweed-infested rangelands until green grass is abundant and locoweed begins to mature.
\end{abstract}

Key Words: Poisonous plant, white locoweed, Oxytropis sericea, cattle grazing

Emaciation is one of the principal signs of locoweed poisoning (James et al. 1981). Chronic locoweed poisoning may also result in reduced weight gains, or weight loss in livestock grazing locoweed infested rangelands. Barnard (1984) reported calves grazing white locoweed (Oxytropis serecia Nutt. ex T\&G) gained $9 \mathrm{~kg}$ less than calves in an adjacent pasture that was not infested with locoweed on mountain summer rangeland in northwestern Utah. James et al. (1970) reported sheep fed spotted locoweed (Astragalus lentiginosus Dougl. ex Hook), Greenriver milkvetch (Astragalus pubentissimus $\mathrm{T} \& \mathrm{G}$ ) or white locoweed for $12 \%$ of their diets gained more than control sheep for the first 2 weeks, but thereafter lost weight for the remainder of an 8 week trial. In

The Authors wish to thank Eric Thacker and Less Owens for assistance in collecting bite count data, and Jane Chambers and Miranda Gordon for the swainsonine analysis.

Manuscript accepted 28 Mar. 1999.

\section{Resumen}

La inanición es uno de los síntomas clínicos de intoxicación por "Loco weed", sin embargo, pocos estudios han documentado los impactos de la intoxicación por "Loco weed" en las ganancias de peso. Durante 1996 y 1997, novillos cruzados (British $x$ Continental) de 200 a $210 \mathrm{~kg}$ de peso apacentaron en el norte de New Mexico una pradera de pastizal corto infestado de "Loco weed". Cada año a la mitad de los novillos se les condicionó una aversión al "Loco weed" para que apacentaran en el pastizal sin consumir "Loco weed". Estos novillos no consumieron "Loco weed" y gradualmente ganaron peso $(0.49 \mathrm{~kg}$ dia-1 en $1996, \mathrm{y}$ $0.71 \mathrm{~kg}$ dia-1 en 1997). Al otro grupo de novillos se le permitió consumir "Loco weed" bajo condiciones naturales de apacentamiento y se intoxicaron. Las ganancias de peso no se afectaron en las primeras 3 semanas, pero de allí en adelante perdieron peso en ambos años. En 1996, los novillos sin aversión consumieron "Loco weed", en promedio el $20 \%$ de las mordidas de estos animales fueron de "Loco weed". Estos novillos se intoxicaron severamente y no ganaron peso por un período de 50 días hasta que dejaron de consumir "Loco weed". En el ensayo de 1997, los novillos consumieron menos "Loco weed" (11\% de las mordidas) que en el ensayo de 1996, y se recuperaron mas rápidamente En 1996 y 1997, la ganancia de peso estacional para los novillos intoxicados fue de 21 y $30 \mathrm{~kg}$ menos que la de los novillos sin intoxicar. El envenenamiento por "Loco weed" causará perdidas de peso, y para que el ganado intoxicado inicie a ganar peso nuevamente se requeriran de largos períodos de recuperación después de que dejaron de consumir "Loco weed". El ganado no debe meterse en potreros infestados con "Loco weed" hasta que haya abundante zacate verde y el "Loco weed" inice la maduración.

a pathological study, Stegelmeier et. al. (1995b) fed rats woolly locoweed (Astragalus mollissimus Torr.) and injected others with the locoweed toxin swainsonine at 0.1 to $15 \mathrm{mg} / \mathrm{kg} \mathrm{BW}$. Rats consuming locoweed or injected with swainsonine at $0.7 \mathrm{mg} / \mathrm{kg}$ and above gained $38 \%$ less weight and intake declined $28 \%$ over the 4 week trial.

Short-grass prairies from northern Mexico to Montana are important summer grazing areas for stocker cattle. Many of these rangelands are infested with Oxytropis and Astragalus locoweeds. The objective of this study was to compare weight gains of locoweed-intoxicated steers to gains of non-intoxicated steers grazing the same pastures. 


\section{Methods}

Field grazing studies were conducted at 2 locations in northeast New Mexico in the spring and early summer of 1996 and 1997.

\section{Trial}

This trial began at the New Mexico State Univ. Research Ranch located $30 \mathrm{~km}$ northeast of Maxwell New Mexico. The site was a short-grass prairie dominated by the warm season grass blue gramma (Bouteloua gracilis (H.B.K.) Lag. ex Steudel). Cool season grasses, western wheatgrass (Pascopyrum smithii (Rybd.) A. Love) and sleepy grass (Stipa robusta Scribn.) were abundant in the swales, and squirreltail (Elymus elymoides (Raf.) Swezey) grew on the ridges. White locoweed was the dominant forb, but fringed sage (Artemisia frigida Willd.) and globe mallow (Sphaeralcea coccinea (Nutt.) Rydb.) were abundant. A 12 ha area was selected on a rocky ridge where white locoweed was dense. The site was split into four, 3 ha pastures with electric fence.

Twenty six crossbred steers (British X Continental, $200 \mathrm{~kg} \pm 4 \mathrm{SE}$ ) were purchased from a local auction and randomly placed in 2 groups: Loco-eaters or Averted. The averted group was conditioned to avoid eating locoweed to prevent them from becoming intoxicated (Ralphs et al. 1997). Steers were fasted overnight then offered fresh picked locoweed. All steers were observed eating the plant and were gavaged with lithium chloride $(\mathrm{LiCl})$ at $200 \mathrm{mg} / \mathrm{kg} \mathrm{BW}$ to induce gastrointestinal illness. They associated the induced illness with the taste of the plant and subsequently refused to eat locoweed. Averted steers were held in the pen for 3 days and allowed to recover, then offered locoweed again to validate the aversion. The aversion treatment allowed the Averted groups to graze on the same sites as the Loco-eaters without becoming intoxicated.

The Loco-eaters were not treated with $\mathrm{LiCl}$ and were allowed to graze the locoweed infested areas under natural grazing conditions. The 2 treatment groups were divided into 2 replications and randomly allocated to the 4 pastures. The 4 sub-groups were rotated through the 4 pastures on a weekly basis to reduce any pasture bias.

Steers were weighed on site at the beginning of the trial on 25 April and blood samples were taken from the jugular vein. Steers were weighed and bled at 2 week intervals. They were fasted overnight and weighed between 0730 and 0900 hours the next morning. Blood samples were centrifuged at 2000 RPM for 20 min. Serum was decanted and frozen until analysis. Serum samples were analyzed for the locoweed toxin, swainsonine, as a measure of level of intoxication by the method described by Stegelmeier et al. (1995a). Swainsonine inhibits the enzyme -mannosidase. Serum samples were incubated for $30 \mathrm{~min}$ with $\alpha$-mannosidase, then quantified photometrically and compared to a standard curve of increasing swainsonine concentration.

Diets were estimated by a bite count technique. Each animal was observed for 5 min periods and the number of bites of cool-season grasses, warm-season grasses, forbs and locoweed were recorded and their percentage of diets were calculated. Generally, 2 observations were made of each steer each day throughout the trial (25 April-19 June ). Vibra-corders were placed on the neck of 4 steers in each group to record the amount of time steers were in a grazing mode. Recording charts were changed on a weekly basis and the amount of time steers spent grazing each day was calculated.

The 2 Loco-eater groups sought-out locoweed and quickly depleted it in the 2 pastures they were grazing. After 5 days, they were rotated to the 2 other pastures, but they grazed most of the locoweed in those 2 pastures by the 10 th day. The spring of 1996 was extremely dry and there was little vegetation growth. Steers were weighed and bled on 8 May, then moved to a new location $30 \mathrm{~km}$ north near Capulin that had more locoweed.

The new site was an old field that had reverted to short-grass prairie. Blue gramma and western wheatgrass dominated the vegetation. White locoweed was abundant on a 6.5 ha tract. This site and an adjacent 6.5 ha site of similar grass composition, were fenced with electric fence. The Locoeater group was placed in the pasture with abundant locoweed and the Averted group was placed in the adjacent pasture that did not have locoweed. The original replications were not maintained due to the limited locoweed and the inability to rotate pastures and still maintain access to locoweed for the Loco-eater group.

The Loco-eater group depleted the locoweed in this pasture and were moved to another locoweed-infested pasture ( 8 ha) $0.5 \mathrm{~km}$ to the north on 20 May. The Averted group was allowed to graze the entire 13 ha of the original pastures at the second site. During the intoxication peri- od, both groups had access to essentially the same type of vegetation. However, forage available to the Averted group may have been somewhat less, since they were held on the 13 ha pasture that had been previously grazed by the Loco-eater steers.

Seasonal rains began on 25 May. Abundant precipitation and warm temperatures allowed for adequate forage throughout the remainder of the trial. The steers were then transported back to the New Mexico State Univ. Research Ranch on 19 June and allowed to graze with other stocker cattle until 14 August, when a final weight was taken.

\section{Trial}

This trial was also conducted at the New Mexico State Univ. Research Ranch near Maxwell, New Mexico. Precipitation was above average during the 1997 growing season, resulting in abundant locoweed and grass. A gravely hill side (15 ha) was selected for the grazing trial. Juniper (Juniperus osteosperma (Torr.) Little) was present on the ridges, and sleepy grass and western wheatgrass (cool-season species) dominated the swales. Blue gramma and purple 3-awn (Aristida purpurea Nutt.) dominated the slopes. White locoweed was abundant on the shallow rocky areas. The site was split into 4 pastures with electric fence.

Twenty two steers were purchased (210 $\mathrm{kg}$ ) and randomly separated into 2 groups: Loco-eaters and Averted. The Averted group was conditioned to avoid eating locoweed as described previously. The groups were divided into 2 replications and randomly allotted to the 4 pastures on 28 April. Steers were rotated through the pastures on a weekly basis to reduce pasture bias. Bite counts ( $5 \mathrm{~min} / \mathrm{steer}$ ) were taken to estimate diets. The steers were weighed and bled every 3 weeks.

The Loco-eaters stopped grazing locoweed by 10 June. All the steers were moved to an adjacent 9 ha pasture and grazed together for the remainder of the trial. Intensive weighing, bleeding and bite counts stopped on 2 July, but the steers remained on site and a final weight was taken on 19 August.

Standing crop was estimated as steers began grazing in each pasture in each trial. Ten, $0.25 \times 1 \mathrm{~m}$ quadrats were systematically located at 20 step intervals along transects running through the center of each pasture. Species were grouped into forage classes (cool-season grasses, warmseason grasses, forbs, and locoweed) clipped at ground level, dried in a forced 
Table 1. Mean standing crop of forage classes $(\mathrm{kg} / \mathrm{ha} \pm \mathrm{SE})$ averaged over pastures at the beginning of grazing trials in 1996 and 1997.

\begin{tabular}{llllll}
\hline \hline Year & Location & $\begin{array}{l}\text { Cool- } \\
\text { season } \\
\text { grasses }\end{array}$ & $\begin{array}{l}\text { Warm- } \\
\text { season } \\
\text { grasses }\end{array}$ & Forb & Locoweed \\
\hline \multirow{2}{*}{1996} & Maxwell & $26 \pm 11$ & $499 \pm 53$ & $263 \pm 6$ & $262 \pm 129$ \\
& Capulin & $52 \pm 15$ & $450 \pm 40$ & $200 \pm 19$ & $134 \pm 33$ \\
1997 & Maxwell & $38 \pm 9$ & $293 \pm 23$ & $145 \pm 23$ & $302 \pm 74$ \\
\hline
\end{tabular}

air oven at $60^{\circ} \mathrm{C}$ for 48 hours, and weighed. Beginning standing crop is presented in Table 1.

\section{Statistical Analysis}

Forage classes in diets (cool-season grass, warm-season grass, forbs, and locoweed) were compared among groups in a split-plot design over time using general linear models (GLM). Steers were nested within groups and used to test differences between groups. Weigh periods were the split plot and the period X steerwithin group factor was used to test the period and the group $\mathrm{X}$ period interaction.

Average daily gains over weigh periods were compared between the 2 groups in a repeated measures model using GLM. In trial 1 , the steers were moved to new locations and the original replications were consolidated into the 2 treatment groups. Steers were nested within groups and weigh periods were the repeated factor. Data from the vibra-corders on time spent grazing in 1996 were analyzed in a similar model comparing groups, with weeks as the split plot.

In trial 2, each treatment group was divided into 2 replications and each treatment group/replication combination was rotated through each pasture to minimize pasture bias. However, there was a treatment group $\mathrm{X}$ replication interaction

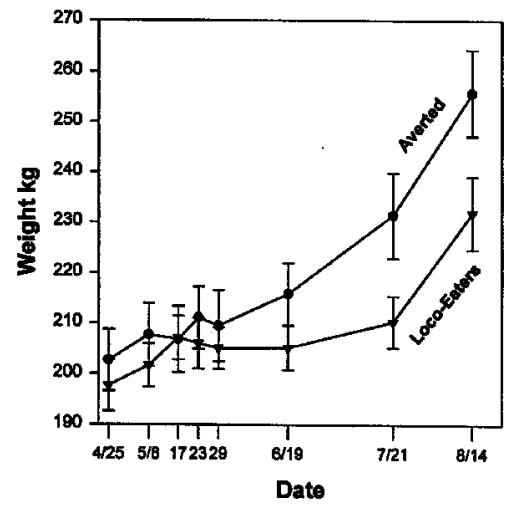

Fig 1. Weight gains of steers that ate locoweed and became intoxicated (locoeaters), compared to steers that were averted from eating locoweed (averted) in the 1996 trial.
$(\mathrm{P}<0.05)$. Loco-eater Replicate 2 started eating locoweed, but quit after 8 days and did not become intoxicated. Replicate 1 continued eating locoweed and became visibly intoxicated. The Averted treatment group and Loco-eater Replicate 2 were combined into a single group for the weight gain data analysis. The model was reduced and data were analyzed for the 2 reconstituted groups using repeated measures GLM, with animals nested within groups, and weigh periods as the repeated factor. Total weight gains and overall ADG were compared by 1-way ANOVA each year. Correlation analysis was run between percent of locoweed in diets, swainsonine concentration in blood serum, and average daily gains for the Loco Group in both years.

\section{Results}

\section{Trial}

Averted cattle did not consume any locoweed (Table 2). Steers in the Locoeater group consumed locoweed for an average of 31 and $27 \%$ of bites during intoxication periods 1 and 2 respectively,

Table 2. Forage classes in diets $(\%$ of bites \pm SE) of steers eating locoweed and steers averted toprevent locoweed consumption, 1996.

\begin{tabular}{|c|c|c|c|c|c|}
\hline Group & Period & $\begin{array}{c}\text { Cool- } \\
\text { season } \\
\text { grass }\end{array}$ & $\begin{array}{c}\text { Warm- } \\
\text { season } \\
\text { grass }\end{array}$ & Forb & Locoweed \\
\hline & & $\ldots$ & $-\ldots(\%$ & s) - - - - - & -1 \\
\hline \multirow[t]{5}{*}{ Loco-eaters } & 1 Intoxication & $15 \pm 1$ & $41 \pm 2$ & $13 \pm 1$ & $31 \pm 2$ \\
\hline & $4 / 25-5 / 16$ & $40 \pm 3$ & $18 \pm 2$ & $16 \pm 2$ & $27 \pm 3$ \\
\hline & $\begin{array}{c}2 \text { Intoxicated } \\
5 / 17-5 / 28\end{array}$ & $40 \pm 3$ & $18 \pm 2$ & $16 \pm 2$ & $27 \pm 3$ \\
\hline & $\begin{array}{l}3 \text { Recovery } \\
5 / 29-6 / 19\end{array}$ & $12 \pm 2$ & $81 \pm 2$ & $7 \pm 1$ & 0 \\
\hline & Mean & $19 \pm 1 \mathrm{a}$ & $50 \pm 1 b$ & $12 \pm 1 \mathrm{a}$ & $20 \pm 1 \mathrm{a}$ \\
\hline \multirow[t]{4}{*}{ Averted } & $\begin{array}{l}1 \text { Intoxication } \\
4 / 25-5 / 16\end{array}$ & $60 \pm 2$ & $33 \pm 2$ & $7 \pm 1$ & 0 \\
\hline & $\begin{array}{l}2 \text { Intoxicated } \\
5 / 17-28\end{array}$ & $33 \pm 3$ & $48 \pm 3$ & $18 \pm 2$ & 0 \\
\hline & $\begin{array}{c}3 \text { Recovery } \\
5 / 29-6 / 19\end{array}$ & $7 \pm 1$ & $86 \pm 1$ & $5 \pm 1$ & 0 \\
\hline & Mean & $34 \pm 2 \mathrm{a}$ & $57 \pm 1 \mathrm{a}$ & $8 \pm 1 \mathrm{a}$ & $0 \mathrm{~b}$ \\
\hline
\end{tabular}

${ }^{\mathrm{ab}}$ Means of forage classes between groups (within columns) that are not followed by the same letter are differen $(\mathrm{P}<0.05)$ and reached a high daily consumption of $80 \%$ of bites. They reduced locoweed consumption and ceased grazing locoweed after 28 May. Other studies reported cattle ceased grazing locoweed when warm season grasses started rapid growth and locoweed matured (Ralphs et al. 1993 . 1997).

Loco-eaters gained $0.45 \mathrm{~kg} /$ day during the first intoxication period, but then lost weight during the 2 nd period (Table 3 ). They did not gain during the recovery period (3), and gained less than the Averted steers $(\mathrm{P}=0.02)$ during the longterm period 4 . They apparently recovered by mid July, and daily gains were comparable with the Averted group for the remainder of the trial (Fig. 1). Total season gains were $21 \mathrm{~kg}$ less $(\mathrm{P}=0.02)$ than the Averted group (Table 3 ). Data from the vibra-corders suggested that Locoeaters grazed for less time than steers in the Averted group (9.4 vs 10.8 hours day ${ }^{-1}$, $\mathrm{P}=0.03$ )

\section{Trial}

There was a treatment $\mathrm{X}$ replication interaction in locoweed consumption $(\mathrm{P}<$ 0.05). Steers in the Loco-eater Replicate 2 ate locoweed at the beginning of the trial (6\% of bites), but stopped after 8 days (Table 4). Steers in Replicate 1 consumed locoweed for an average of 19 and $10 \%$ of bites in periods 1 and 2 . They consumed little locoweed during the recovery period. The Averted group consumed no locoweed.

There was no difference in weight gains between the Averted group and steers in 
Table 3. Average daily gains and total gains ( \pm SE) of steers consuming locoweed and becoming intoxicated, compared with steers averted to prevent locoweed consumption, 1996.

\begin{tabular}{|c|c|c|c|}
\hline$\overline{\overline{\text { Period }}}$ & Loco-eaters & Averted & $\mathrm{p}$ \\
\hline $\begin{array}{l}\text { 1Intoxication } \\
4 / 25-5 / 16\end{array}$ & $\begin{array}{c}0.45 \pm 0.10 \\
0 .-1\end{array}$ & $\begin{array}{l}0.19 \pm 0.12 \\
0 .-\cdots\end{array}$ & 0.25 \\
\hline $\begin{array}{l}2 \text { Intoxicated } \\
5 / 17-5 / 28\end{array}$ & $-0.01 \pm 0.20$ & $0.25 \pm 0.26$ & 0.43 \\
\hline $\begin{array}{l}3 \text { Recovery } \\
5 / 29-6 / 18\end{array}$ & $0.02 \pm 0.09$ & $0.31 \pm 0.10$ & 0.07 \\
\hline $\begin{array}{l}4 \text { Recovery } \\
6 / 19-7 / 20\end{array}$ & $0.17 \pm 0.10$ & $0.51 \pm 0.090 .02$ & \\
\hline $\begin{array}{l}5 \text { Long term } \\
7 / 21-8 / 14\end{array}$ & $0.91 \pm 0.11$ & $1.10 \pm 0.13$ & 0.29 \\
\hline Overall ADG & $0.29 \pm 0.05$ & $0.49 \pm 0.04$ & 0.01 \\
\hline Total gain & $\begin{array}{c}33 \pm 6.1 \\
33\end{array}$ & $54 \pm 4.4$ & 0.02 \\
\hline
\end{tabular}

Loco-eater Replicate 2 ( $\mathrm{P}>0.05)$. Therefore, we combined these groups and compared their weight gains with steers in Loco-eater Replicate 1, which became visibly intoxicated. There was no difference in gains during the initial 3 week intoxication period (Table 5). During the next 30 days, loco-eaters lost weight while the Non-eaters gained $0.27 \mathrm{~kg} /$ day $(\mathrm{P}=0.01)$. During recovery period 3 , gains were similar. However, during the long-term period 4, Loco-eater gains were significantly lower $(\mathrm{P}<0.01)$ than the Non-eaters (Fig.

2). Total seasonal gains were $30 \mathrm{~kg}$ less $(\mathrm{P}<0.01)$ in the Loco-eater group (Table 5).

\section{Swainsonine in Blood}

Swainsonine concentration in blood serum followed trends similar to locoweed consumption in both years (Fig. 3). In 1996, swainsonine peaked on 23 May at $453 \mathrm{~g} / \mathrm{ml}$, and then started to decline after 29 May as steers stopped eating locoweed. Lower swainsonine levels in 1997 resulted from lower locoweed intake (Table 3 ).

Table 4. Forage classes in diets (\% of bites \pm SE) of steers in Loco group (Rep 1 and 2 ) and steers in Averted group, 1997.

\begin{tabular}{|c|c|c|c|c|c|}
\hline Group Rep & Period & $\begin{array}{l}\text { Cool- } \\
\text { season } \\
\text { grass }\end{array}$ & $\begin{array}{l}\text { Warm- } \\
\text { season } \\
\text { grass }\end{array}$ & Forb & Locoweed \\
\hline \multirow[t]{4}{*}{$\begin{array}{l}\text { Loco } 1 \\
\text { (loco-eaters) }\end{array}$} & $\begin{array}{c}1 \text { Intoxication } \\
4 / 28-5 / 16\end{array}$ & $22 \pm 3$ & $54 \pm 3$ & $5 \pm 1$ & $19 \pm 2$ \\
\hline & $\begin{array}{l}2 \text { Intoxicated } \\
5 / 17-5 / 28\end{array}$ & $12 \pm 2$ & $63 \pm 2$ & $15 \pm 1$ & $10 \pm 1$ \\
\hline & $\begin{array}{c}3 \text { Recovery } \\
6 / 17-7 / 1\end{array}$ & $35 \pm 4$ & $58 \pm 4$ & $6 \pm 1$ & $1 \pm 1$ \\
\hline & Mean & $19 \pm 2 a$ & $59 \pm 2 b$ & $10 \pm 1 \mathrm{a}$ & $11 \pm 1 \mathrm{a}$ \\
\hline \multirow[t]{4}{*}{$\begin{array}{l}\text { Loco } 2 \\
\text { (non-eaters) }\end{array}$} & $\begin{array}{c}1 \text { Intoxication } \\
4 / 28-5 / 16\end{array}$ & $8 \pm 1$ & $78 \pm 2$ & $8 \pm 1$ & $6 \pm 1$ \\
\hline & $\begin{array}{l}2 \text { Intoxicated } \\
5 / 17-6 / 16\end{array}$ & $8 \pm 1$ & $87 \pm 1$ & $5 \pm 1$ & 0 \\
\hline & $\begin{array}{c}3 \text { Recovery } \\
6 / 17-7 / 1\end{array}$ & $13 \pm 2$ & $78 \pm 2$ & $9 \pm 1$ & 0 \\
\hline & Mean & $9 \pm 1 c$ & $82 \pm 1 a$ & $7 \pm 1 b$ & $2 \pm 1 b$ \\
\hline \multirow[t]{4}{*}{$\begin{array}{l}\text { Averted } \\
\text { (non-eaters) }\end{array}$} & $\begin{array}{c}1 \text { Intoxication } \\
4 / 28-5 / 16\end{array}$ & $18 \pm 2$ & $78 \pm 2$ & $4 \pm 1$ & 0 \\
\hline & $\begin{array}{l}2 \text { Intoxicated } \\
5 / 17-28\end{array}$ & $11 \pm 1$ & $82 \pm 1$ & $7 \pm 1$ & 0 \\
\hline & $\begin{array}{c}3 \text { Recovery } \\
6 / 17-7 / 1\end{array}$ & $16 \pm 2$ & $76 \pm 2$ & $7 \pm 1$ & 0 \\
\hline & Mean & $14 \pm 1 b$ & $80 \pm 1 \mathrm{a}$ & $6 \pm 1 b$ & $0 \mathrm{~b}$ \\
\hline
\end{tabular}

${ }^{\mathrm{ab}}$ Means of forage classes between groups (within columns) that are not followed by the same letter are different $(\mathrm{P}<0.05)$.

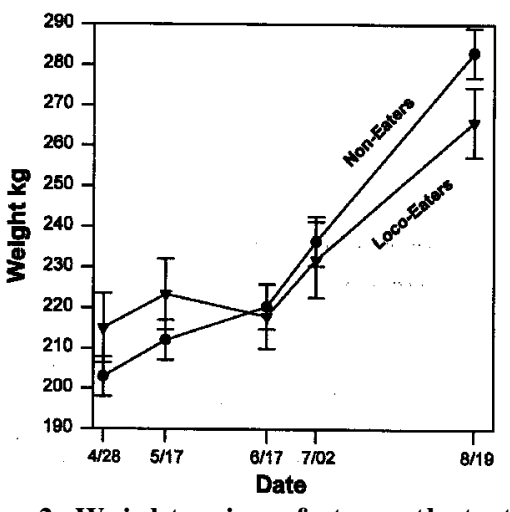

Fig. 2. Weight gains of steers that ate locoweed and became intoxicated (locoeaters), compared to steers that were averted to locoweed and steers in Rep 2 that did not eat locoweed (non-eaters) in the 1997 trial.

Although weight loss during intoxicated period 2 was similar in both years, steers recovered much faster in 1997 because they were not as severely intoxicated.

Swainsonine concentration in blood serum was positively correlated with locoweed consumption $(\mathrm{r}=0.65)$, but there was little correlation with weight gains $(\mathrm{r}<-0.21)$. Swainsonine is rapidly cleared from the blood once animals stop eating locoweed (Stegelmeier et al. 1995a). Steers in the Loco group stopped eating locoweed in June, but weight gains did not resume for a period of time after the steers started to recover.

\section{Discussion}

Averted steers and steers that were not intoxicated by locoweed gained an average of $0.49 \mathrm{~kg} / \mathrm{day}$ in 1996 and 0.71 $\mathrm{kg} /$ day in 1997. Gains on similar shortgrass prairie in central New Mexico averaged $0.82 \mathrm{~kg} /$ day over the summer grazing season (Parker et al. 1987). In central Kansas, summer gains averaged 0.63 $\mathrm{kg}$ /day (Olsen et al. 1993).

Locoism is a chronic disease. Even though maximum locoweed consumption occurred at the beginning of the trials (up to $80 \%$ of bites), weight gains were not affected during the first 3 weeks either year. James et al. (1970) reported sheep on locoweed diets gained more than control sheep during the first 2 weeks of an 8 week feeding trial; and ewes visibly improved in body condition when they first started grazing locoweed in a winter grazing study (James et al. 1968). Locoweed is a succulent cool-season forb containing $>60 \%$ moisture and up to $20 \%$ crude protein (Ralphs et al. 1993). It is 


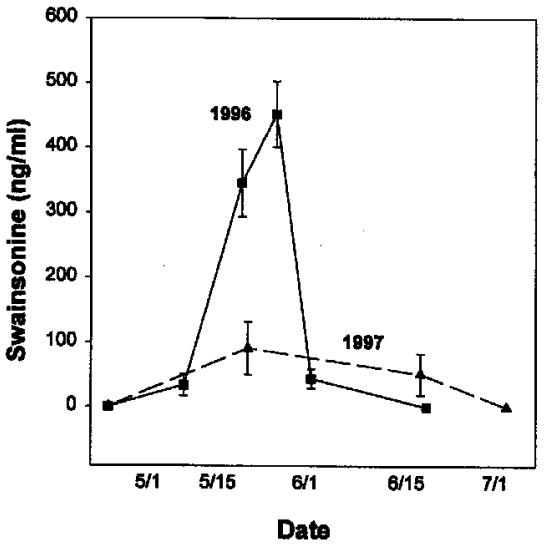

Fig. 3. Swainsonine level in blood serum of loco-eater steers in 1996 and 1997.

nutritionally superior to dormant warm season grasses during the spring and may provide a nutritional boost before the damage from swainsonine accumulates.

Following the initial flush of gains, steers eating locoweed lost weight in both years. From the time steers in the 1996 trial stopped eating locoweed (around the end of May), it took 50 days before they started gaining at a rate similar to nonintoxicated steers (Fig. 1). In the 1997 trial, steers greatly reduced locoweed consumption by the first of June. During recovery period 3 from 17 June until 2 July, they gained similar to the Noneaters. This appears to be a fairly rapid recovery, and is probably because they consumed less locoweed than the steers in 1996 and were not as intoxicated (Fig. 3). However during the 48-day long-term recovery, they gained $28 \%$ less than the Non-eaters (Fig. 2). Long-term gains in the feedlot may also be compromised (unpublished data, Glen Duff).

Reduction in weight gains or weight loss may be due to either reduced intake or inefficient metabolism of feed. Locoeaters in trial 1 reduced grazing time by 1.4 hours/day compared to Averted steers. Marsh (1909) reported intoxicated cattle grazed less than normal cattle. Ralphs et al. (1991) reported sheep poisoned on locoweed developed tremors in the jaw and did not resume grazing until these seizures passed. Biting rate of intoxicated sheep was $33 \%$ less than control sheep. Neurological damage from locoweed poisoning, which causes depression and reduced motor control in prehending and masticating food, may result in anoxeria and emaciation (Stegelmeier et al. 1995b).

Metabolism of feed may also be impaired. Stegelmeier et al. (1995b) reported locoweed intoxication caused vacuolation of parietal cells in the stomach, which may effect nutrient absorption. Pan et al. (1993) reported swainsonine was a potent inhibitor of digestive enzymes (sucrase, glucosidase, and mannosidase) in the intestinal tract of rats. Although simple sugars are not present in the gut of ruminants, glycolysis may be affected in the liver and other areas of the body.

\section{Management Implications}

Weight gains were not affected by steers grazing locoweed for the first 3 weeks of the trials. Steers that continued eating locoweed during May and early June lost weight. Severely intoxicated steers in 1996 did not begin gaining weight for 50 days after they stopped eating locoweed. Seasonal weight gains were 21 and $30 \mathrm{~kg}$ less for locoed steers than control steers in 1996 and 1997, respectively. Net ranch income was estimated to decline $\$ 75$ and $\$ 282$ per head for moderately and severely poisoned stocker steers (Owens et al. 1999). If stocker cattle remain on

Table 5. Average daily gains and total gains $( \pm S E)$ of steers consuming locoweed and becoming intoxicated, compared with steers that did not eat locoweed, 1997.

\begin{tabular}{|c|c|c|c|}
\hline$\overline{\overline{\text { Period }}}$ & Loco-eaters & Averted & $\mathrm{p}$ \\
\hline $\begin{array}{c}\text { 1Intoxication } \\
4 / 25-5 / 16\end{array}$ & $0.41 \pm 0.10$ & $0.47 \pm 0.10$ & 0.80 \\
\hline $\begin{array}{l}2 \text { Intoxicated } \\
5 / 17-6 / 16\end{array}$ & $-0.18 \pm 0.09$ & $0.27 \pm 0.08$ & 0.01 \\
\hline $\begin{array}{c}3 \text { Recovery } \\
6 / 17-7 / 1\end{array}$ & $0.94 \pm 0.21$ & $1.08 \pm 0.14$ & 0.62 \\
\hline $\begin{array}{l}4 \text { Long term } \\
7 / 2-8 / 19\end{array}$ & $0.71 \pm 0.02$ & $0.97 \pm 0.02$ & 0.0001 \\
\hline Overall ADG & $0.44 \pm 0.04$ & $0.71 \pm 0.02$ & 0.0001 \\
\hline Total gain & $\begin{array}{c}50 \pm 4.2 \\
0\end{array}$ & $80 \pm 2.8$ & 0.007 \\
\hline
\end{tabular}

locoweed-infested pastures, they should not be allowed to enter these pastures until warm season grasses are growing rapidly and locoweed is maturing.

\section{Literature Cited}

Barnard, J.E. 1984. Locoweed poisoning in cattle: An overview of the economic problems associated with grazing these ranges. M.S. Thesis, Utah State Univ. Logan Ut.

James, L.F., W.J. Hartley, K.R. Van Kampen. 1981. Syndromes of Astragalus poisoning in livestock. J. Amer. Vet. Med. Assoc. 178:146-150.

James, L.F., K.R. Van Kampen, and A.E. Johnson. 1970. Physiopathologic changes in locoweed poisoning of livestock. Amer. J. Vet. Res. 31:663-672.

James, L.F., K.L. Bennett, K.G. Parker, R.F. Keeler, W. Binns and B. Lindsay. 1968. Loco plant poisoning in sheep. J. Range Manage. 21:360-365.

Marsh, C.D. 1909. The loco-weed disease of the plains. USDA Bull. 112.

Olson, K.C., J.R. Brethour, and J.L. Launchbaugh. 1993. Shortgrass range vegetation and steer growth response to intensiveearly stocking. J. Range Manage. 46:127-132.

Owens, L.P., L.A. Torell, and D. Graham. 1999. Locoweed poisoning causes economic losses for yearling stocker enterprises. pp. 76-79 T.M. Sterling and D.C. Thompson (Eds), Locoweed Research: Updates and Highlights. New Mex. State. Univ. Res. Rep. 730.

Pan, Y.T., J. Ghidoni, and A.D. Elbein. 1993. The effects of castanospermine and swainsonine on the activity and synthesis of intestinal sucrase. Archives Biochem. Biophysics 303:134-144.

Ralphs, M.H., K.E. Panter and L.F. James. 1991. Grazing behavior and forage preference of sheep with chronic locoweed toxicosis suggests no addiction. J. Range Manage. 44:208-209.

Ralphs, M.H., D. Graham, R.J. Molyneux and L.F. James. 1993. Seasonal grazing of locoweeds by cattle in northeastern New Mexico. J. Range Manage. 46:416-420.

Ralphs, M.H., D. Graham, M.L. Galyean and L.F. James. 1997. Creating aversions to locoweed in naive and familiar cattle. J. Range Manage. 50:361-366.

Parker, E.E., G.B. Donart, R.D. Pieper, J.D. Wallace and J.D. Wright. 1987. Response of range beef cattle to different grazing management systems. New Mexico Agr. Exp. Sta. Bull. 732 .

Stegelmeier, B.L., L.F. James, K.E. Panter, and R.J. Molyneux. 1995a. Serum swainsonine concentration and -mannosidase activity in cattle and sheep ingesting Oxytropis sericea and Astragalus lentiginosus (locoweeds). Amer. J. Vet. Res. 56:149-154.

Stegelmeier, B.L., R.J. Molyneux, A.D. Elbein, and L.F. James. 1995b. The lesions of locoweed (Astragalus mollissimus), swainsonine and castonospermine in rats. Vet. Pathol. 32:289-298. 